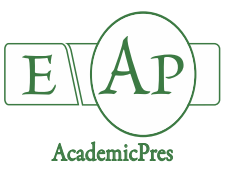

Dubey $S$ et al. (2020)

Notulae Botanicae Horti Agrobotanici Cluj-Napoca 48(2):954-966

DOI: $10.15835 /$ nbha 48211861

Research Article

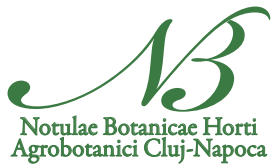

\title{
Effect of salinity stress on yield and quality parameters in flax (Linum usitatissimum L.)
}

\author{
Saijasi DUBEY ${ }^{1}$, Atul BHARGAVA ${ }^{2}$, Francisco FUENTES ${ }^{3}$, \\ Sudhir SHUKLA ${ }^{4}$, Shilpi SRIVASTAVA ${ }^{1 *}$ \\ ${ }^{1}$ Amity University Uttar Pradesh (Lucknow Campus), Amity Institute of Biotechnology, Lucknow-226028, India; \\ saijasidubey@gmail.com; ssrivastaval@lko.amity.edu ("corresponding author) \\ ${ }^{2}$ Mahatma Gandhi Central University, School of Life Sciences, Department of Botany, Motihari, Bihar-845401, India; \\ atulbhargava@mgcub.ac.in \\ ${ }^{3}$ Pontificia Universidad Católica de Chile, Facultad de Agronomía e Ingeniería Forestal, Escuela de Ingeniería, Facultad de Medicina, \\ Santiago,Chile;frfuentesc@uc.cl \\ ${ }^{4}$ National Botanical Research Institute, Division of Genetics and Plant Breeding. Lucknow-226001, India; sshukla31@rediffmail.com
}

\begin{abstract}
Flax is one of the oldest utilitarian plants that have been grown for fibre as well as an oilseed crop. The species has been recognized as an excellent source of micronutrients, dietary fibre, protein, vitamin B1, lignan, and essential fatty acids (EFA), namely linoleic and $\alpha$-linolenic acids. However, in spite of immense nutritional and industrial importance of the crop no work has been carried out on the effect of salinity induced by different salts on seed yield and quality traits in Linum usitatissimum. A high yielding germplasm line 'Mukta' was subjected to five concentrations $(0 \mathrm{mM}, 50 \mathrm{mM}, 100 \mathrm{mM}, 150 \mathrm{mM}$ and $200 \mathrm{mM})$ of three salts viz. sodium chloride $(\mathrm{NaCl})$, potassium chloride $(\mathrm{KCl})$ and calcium chloride $\left(\mathrm{CaCl}_{2}\right)$ for two seasons. Data were collected for seed yield along with different quality traits and a range of antioxidant enzymes. Seed yield decreased with rise in salt concentration and was minimum at $200 \mathrm{mM}$ for all the salts. Chlorophyll a, chlorophyll b and carotenoid content continuously decreased with increase in salt concentration for all the salt treatments. Catalase and GST content increased with increase in salt concentration and was maximum at $200 \mathrm{mM}$.
\end{abstract}

Keywords: antioxidant enzymes; carotenoid; flax; flavonoids; phenolics; salt stress

\section{Introduction}

Environmental conditions are known to exert a strong influence on plant growth and productivity (Feller and Vaseva, 2014; Pandolfi et al., 2017). A number of abiotic factors like salinity, drought and extreme temperatures play a major role in significantly reducing yield along with an adverse impact on several growth parameters (Tardieu, 2013; Bose et al., 2014). Salinity is one of the major abiotic stresses, which has significant impact on plant productivity and quality (Bhargava et al., 2003; Shahbaz and Ashraf, 2013). Soil salinity has significantly increased in recent years due to several factors like excessive irrigation, low precipitation, high surface evaporation, rock weathering, ion exchange and poor cultural practices (Munns and Tester, 2008; Bui, 
2017). Recent reports indicate that about $20 \%$ of total cultivated and $33 \%$ of irrigated lands are afflicted by saline conditions at present, and that more than $50 \%$ of the arable land would be salinized by the year 2050 (Jamil et al., 2011; Shrivastava and Kumar, 2015). Salinity stress negatively affects all growth stages of plants in various ways like reduction of plant height, deterioration of the product quality and crop yields (Shahbaz and Ashraf, 2013; Shrivastava and Kumar, 2015; Rahneshan et al., 2018). Soil salinity is also known to affect different physiological and metabolic processes of plants such as reduction in water uptake, chlorophyll content, photosynthesis, transpiration rate, nutrient availability, stomata conductance and root hydraulic conductance (Khataar et al., 2018; Hernández, 2019).

Flax (Linum usitatissimum L.) is a member of the family Linaceae which comprises of 22 genera and approximately 180 species distributed over six continents (Hickey, 1988; Heywood, 1993; Vromans, 2006; McDill et al., 2009). The genus is divided in five subsections of which subsection Linum contains the cultivated species L. usitatissimum L. and the ornamentals L. grandiflorum and L. perenne (Tutin et al., 1968). It is considered that flax originated in southern Europe, the Near East, or Central Asia (Zeven, 1982; Zohary and Hopf, 2000) and was probably the first plant cultivated for fibre in the Old World (Zohary and Hopf, 2000). A wide karyological heterogeneity has been documented in Linum with chromosome numbers ranging from $2 n=12$ to $2 n=84$ (Kikuchi, 1929; Rogers and Harris, 1966; Harris, 1968; Bari and Godward, 1970; Robertson, 1971; Chennaveeraiah and Joshi, 1983). However, with respect to L. usitatissimum the diploid chromosome has been confirmed as $2 n=30$ chromosomes (Muravenko et al., 2003) and the genome size (1C) as 686 mega base pairs (Mbp) (Bennett and Leitch, 2004). Flax is one of the oldest utilitarian plants that have been grown for fibre as well as an oilseed crop. Linseed oil has been extensively used in paint and flooring industries due to its rapid drying property in comparison with other traditional oils (Bayrak et al., 2010). The species has also been recognized as an excellent source of micronutrients, dietary fibre, protein, vitamin B1, lignan, and essential fatty acids (EFA), namely linoleic and $\alpha$-linolenic acids (Singh et al., 2011; Kajla et al., 2015; Goyal et al., 2016).

However, inspite of immense nutritional and industrial importance of the crop no work has been carried out on the effect of salinity induced by different salts on seed yield, quality traits and antioxidant enzymes in $L$. usitatissimum. Therefore, the objective of the present study was to ascertain up to what extent can yield and quality be influenced by different salts and their concentrations? Principal component analyses (PCA) was carried out using 12 variables to ascertain the main factors that indicate stress situations effectively. This study reports for the first time the effects of different salts on seed yield and quality traits, as well as antioxidant enzyme systems in the species.

\section{Materials and Methods}

\section{Experimental area}

The experiments were conducted at Amity University Uttar Pradesh (Lucknow campus) which is located at $26.5^{\circ} \mathrm{N}$ latitude and $80.5^{\circ} \mathrm{E}$ longitude, and at 120 meter above sea level. This region is characterized by monsoonal climate and two major crop seasons, summer (Kharif-March to July) and winter (Rabi- October to February). L. usitatissimum is cultivated in the rabi season during which the minimum and maximum temperature ranges from $2.5-19^{\circ} \mathrm{C}$ and $14-29^{\circ} \mathrm{C}$ respectively.

\section{Experimental material}

The germplasm line Mukta having its origin at Chandra Shekhar Azad University of Agriculture and Technology, Kanpur, India was obtained from National Botanical Research Institute, Lucknow, India and used as the experimental material. 


\section{Experiment}

The germplasm line Mukta was used in a split plot design for two experimental years (2017 and 2018) with sowing date as the main plot and salts and concentrations as subplots. Sowing was done at the beginning of January month in both 2017 and 2018. The weather parameters prevailing during both the experimental years have been provided in Table 1 . The seeds were surface sterilized in $70 \%$ ethanol for 10 s, and then washed with distilled water at least three times. Thereafter, ten seeds were sown in plastic pots containing vermiculite at depth of one $\mathrm{cm}$. Five concentrations $(0 \mathrm{mM}, 50 \mathrm{mM}, 100 \mathrm{mM}, 150 \mathrm{mM}$ and $200 \mathrm{mM})$ of three salts viz. sodium chloride $(\mathrm{NaCl})$, potassium chloride $(\mathrm{KCl})$ and calcium chloride $\left(\mathrm{CaCl}_{2}\right)$ were given to the germplasm line in two replications. Hoagland's solution was used as a nutrient medium with five additions during the entire growth season. A total of five salt treatments were provided to each pot during the growing season.

Table 1. Weather conditions during the experimental years

\begin{tabular}{|c|c|c|c|c|c|c|}
\hline \multirow{2}{*}{ Experimental year } & \multicolumn{3}{|c|}{ Temperature $\left({ }^{\circ} \mathrm{C}\right)$} & \multicolumn{3}{|c|}{ Humidity (\%) } \\
\hline & Minimum & Maximum & Mean & Minimum & Maximum & Mean \\
\hline \multicolumn{7}{|l|}{2017} \\
\hline January & 2 & 28 & 15 & 29 & 100 & 79 \\
\hline February & 9 & 33 & 19 & 21 & 100 & 63 \\
\hline March & 9 & 42 & 25 & 14 & 100 & 48 \\
\hline April & 17 & 43 & 33 & 9 & 89 & 38 \\
\hline \multicolumn{7}{|l|}{2018} \\
\hline January & 3 & 27 & 12 & 29 & 100 & 82 \\
\hline February & 8 & 34 & 19 & 15 & 100 & 66 \\
\hline March & 13 & 40 & 26 & 16 & 88 & 53 \\
\hline April & 19 & 42 & 31 & 13 & 94 & 45 \\
\hline
\end{tabular}

\section{Parameters recorded}

Data were collected for seed yield along with different quality traits and antioxidant enzymes. The chlorophyll and carotenoid $(\mathrm{mg} / \mathrm{g}$ ) content of fresh leaves of each treatment were analysed following Jensen (1978). The total flavonoid and phenolic contents in leaf samples were spectrophotometrically determined by the method of Kevin et al. (2002) and Fatma et al. (2013), respectively. The flavonoid content was expressed in $\mathrm{mg}$ equivalent $\mathrm{QE} /$ gram of tissue and phenolic content was expressed as mg equivalent gallic acid/gram dry weight. Leaf protein (\%) was estimated as per Bradford (1976). The scavenging ability of the natural antioxidants of the leaves towards the stable free radical DPPH (1,1-diphenyl-2-picrylhydrazyl) was determined by the method of Mensor et al. (2001) and expressed as $\mu \mathrm{g} / \mathrm{mL}$. Reduced glutathione was analysed by method of Ellman (1959) and expressed as $\mu \mathrm{mol} / \mathrm{g} / \mathrm{min}$, while glutathione $S$-transferase (GST) activity was assessed following Habig et al. (1974) and expressed as $\mathrm{mol} / \mathrm{min} / \mathrm{mg}$ protein. Superoxide dismutase (SOD) activity was assayed according to Kakkar et al. (1984), while catalase activity was determined by the method of Aebi (1974) and both were expressed as unit/g fresh weight (U/g fw).

\section{Data analysis}

The results of each year (2017-18 and 2018-19) were statistically analysed separately by analysis of variance according to the split plot model using Windostat software program. Differences between means were separated using Tukey's test. Principal component analysis (PCA) (Hair et al., 1992) of a treatment/variable x year matrix, containing standardized trait data, was analysed through a biplot constructed by plotting the symmetrically scaled principal component 1 (PC1) scores against the principal component 2 (PC2) scores by using InfoStat ${ }^{\oplus}$ (Infostat, 2019) statistical software. All comparisons were made at the $5 \%$ level of significance $(\mathrm{p} \leq 0.05)$. 


\section{Results and Discussion}

The analysis of variance showed significant differences among the salts for all the traits except flavonoids, phenolics and GST content for both the experimental years (data not shown). Also, significant differences were observed for salt concentrations for all the traits under study in both the years (data not shown).

In order to assess the patterns of variations, principal components analysis (PCA) was done considering all the 12 variables simultaneously. The first two principal components, PC1 and PC 2, that explained 63.9 and $22.0 \%$ of the total variance of measured traits were applied to make a score (Figure 1). All the variables except catalase, GST and DPPH had positive scores on PC1, while DPPH, SOD and chlorophyll a had highest value for PC2. It was interesting to note that in the PCA score plot, the treatments with lower salt concentrations $(50$ and $100 \mathrm{mM}$ ) were placed closely and were far apart from treatments with high salt concentrations (150 and $200 \mathrm{mM}$ ). This indicated that higher salt concentrations induced somewhat similar effects on quality traits and antioxidant parameters.

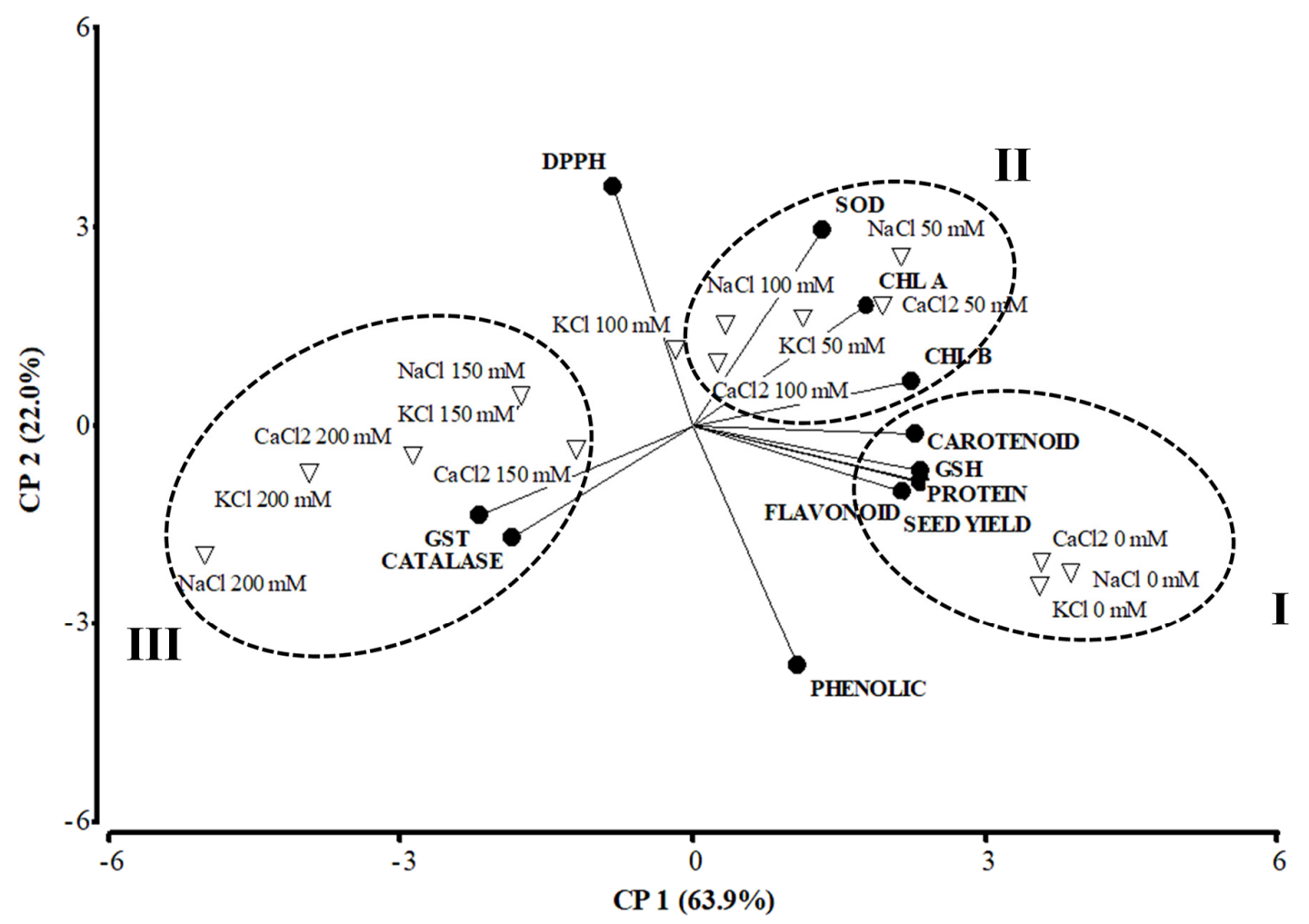

Figure 1. The score plot for the first two principal components explaining $85.9 \%$ of the variance of all salt treatments and measured variables included in the principal component's analysis

During K stress, both chlorophyll a and chlorophyll b initially increased on salt treatment at $50 \mathrm{mM}$, but thereafter continuously decreased for both the experimental years and were lowest for $200 \mathrm{mM} \mathrm{KCl}$ (Table 2). Chlorophyll a recorded a decrease of about $10 \%$ in 2017 at $200 \mathrm{mM} \mathrm{KCl}$ as compared to control plants. The fall was more drastic for chlorophyll b which reduced to about $50 \%$ at $200 \mathrm{mM}$ in both the experimental years. As salt concentration increased, $\mathrm{CaCl}_{2}$ and $\mathrm{NaCl}$ also had significant impact on chlorophyll content though not in a definite pattern. The decrease in chlorophyll during salt stress could be attributed to increased activity of chlorophyllase enzyme or salt induced weakening of protein-pigment lipid complex (Strogonov, 1970; Sivtsev et al., 1973). It was interesting to note that the carotenoid content continuously decreased with 
increase in salt concentration for all the salt treatments (Table 2). However, the decrease was more pronounced during $\mathrm{Ca}$ and $\mathrm{Na}$ stress. Generally lowest reduction in the carotenoid content was witnessed in both the experimental years during K stress (Table 2). Similar decrease in leaf pigment concentrations in increasing levels of soil salinity has earlier been reported in other plants like Phaseolus vulgaris (Taibi et al., 2016), Acacia auriculiformis (Rahman et al., 2017) and Triticum aestivum (Shah et al., 2017). The effect of salinity stress on plant pigments is highly specific and can be attributed to stomatal closure and mesophyll limitations for the diffusion of gases that leads to impaired photosynthetic process (Hu et al., 2005; Chaves et al., 2009; Tang et al., 2013).

Table 2. Mean values for flax leaf pigments during salt stress

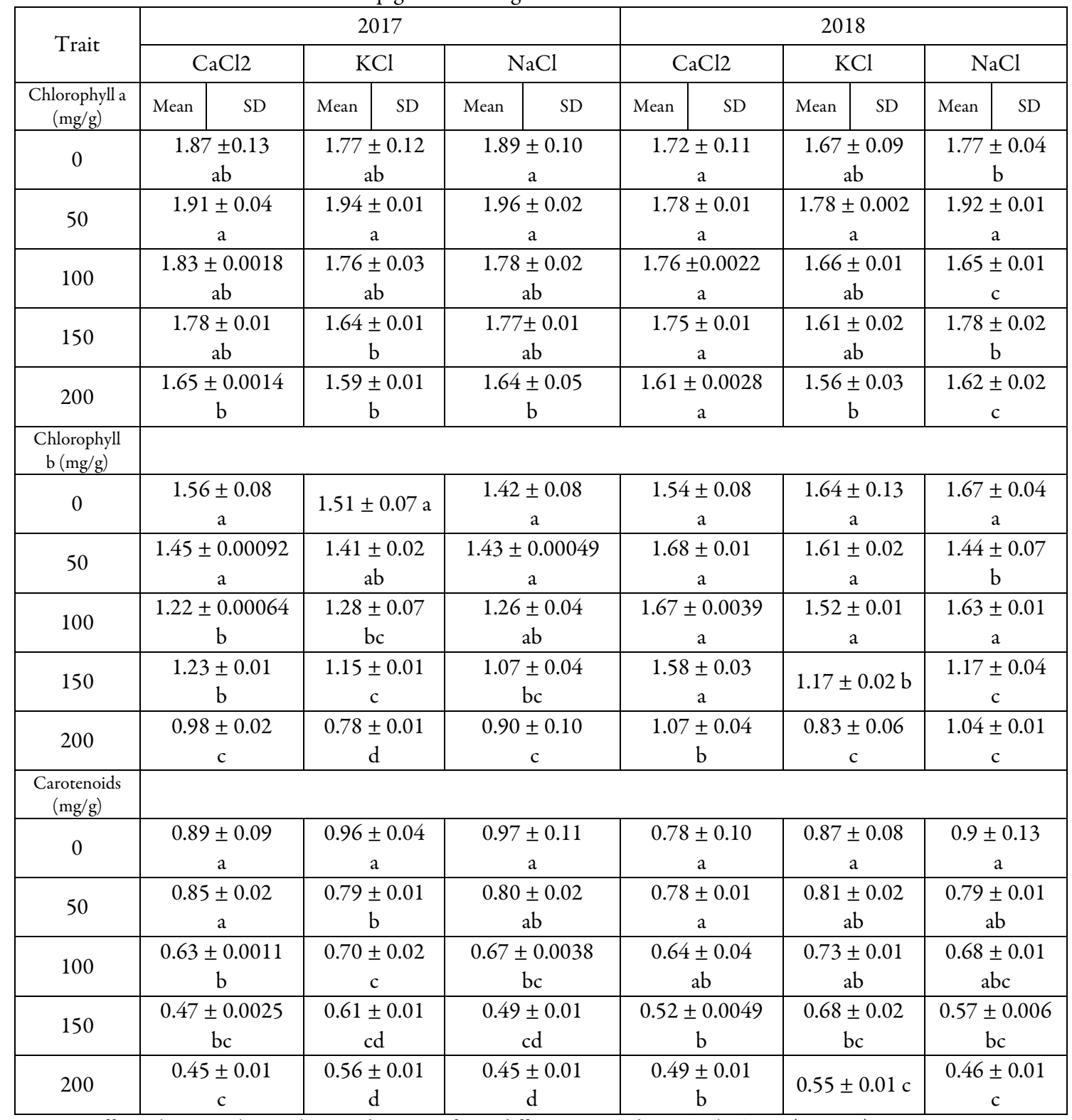

Different letters within a column indicate significant differences according to Tukey's test $(\mathrm{p} \leq 0.05)$. 
Phenolics are a large and diverse group of aromatic compounds found throughout the plant kingdom which possess at least one aromatic ring $\left(\mathrm{C}_{6}\right)$ and one or more hydroxyl groups (Boudet, 2007; Dai and Mumper, 2010). This ubiquitous group of most abundant secondary metabolites are ubiquitous in all plant organs with over 8000 structures reported so far (Manach et al., 2004; Bhattacharya et al., 2010; Dai and Mumper, 2010). Plant phenolics have recently drawn increasing attention due to their potent antioxidant properties, as protective agents, inhibitors, natural animal toxicants, pesticides and in the prevention of diseases associated with oxidative stress (Sowndhararajan and Kang, 2013; Arora et al., 2019; Durazzo et al., 2019). The concentration of phenolics reduced significantly at $50 \mathrm{mM}$ salt concentration but thereafter continuously increased with increase in salt concentration and was maximum at $200 \mathrm{mM}$ for all the three salts in both the experimental years (Table 3). This increase in phenolic content during salt stress has been attributed to disturbances in the secondary metabolic pathways (Ksouri et al., 2007). The phenolic content in flax leaves was higher than that reported in flax seeds (Oomah et al., 1995; Russo and Reggiani, 2015). Such high concentrations in phenolics in plant leaves as compared to other parts like flower, root, stem and fruit have also been earlier reported in Lantana camara (Family Verbenaceae) (Mahdi-Pour et al., 2012).

Flavonoids are low molecular weight secondary plant metabolites that exhibit wide distribution in most of the plant parts viz. leaves, seeds, bark and flowers (Tohge et al., 2013). Flavonoids, characterized by the flavan nucleus, have a broad range of functions in plants ranging from pollination and seed dispersal to protection against various abiotic and biotic stresses (Jiang et al., 2016; Yonekura-Sakakibara et al., 2019). Flavonoids have been associated with numerous biological properties and also confer various human health-related benefits (Kawai, 2018; Fraga et al., 2019). In the present study, the flavonoid content continuously decreased with increase in salt concentration for all the salt treatments. However, the decrease was maximum during $\mathrm{K}$ stress in 2017 and Na stress in 2018 (Table 3). The flavonoid content was highest during calcium stress for all salt concentrations in both the experimental years (Table 3). Also, moderate amount of protein content was reported in flax leaves which was highest during sodium stress (Table 3). Similar to flavonoids, the protein content was significantly lower at higher salt concentrations in both the experimental years. The protein content reduced to almost half at $50 \mathrm{mM} \mathrm{K}$ concentration and fell further at $200 \mathrm{mM} \mathrm{K}$ concentration in 2017. In 2018 , the fall in protein was maximum for $\mathrm{Na}$ at $2.90 \%$ that indicated a fall of about $95 \%$ as compared to control in the quality parameter.

Seed yield presented interesting results during the course of the study. At higher salt concentrations (150 and $200 \mathrm{mM}$ ), seed yield reduced significantly in both the experimental years (Table 3). Seed yield continuously decreased with rise in salt concentration and was minimum at $200 \mathrm{mM}$ for all the salts (Table 3). The reduction was most pronounced under Ca stress with seed yield reducing to $0.10 \pm 0.01 \mathrm{~g} / \mathrm{plant}$ and $0.08 \pm 0.03 \mathrm{~g} / \mathrm{plant}$ at $200 \mathrm{mM}$ salt concentrations for 2017 and 2018, respectively. Less reduction in seed yield was observed during $\mathrm{Na}$ stress.

In nature, plants encounter a variety of stress conditions like supra-optimal light, water deficit, salinity, radiation, pathogens, chemicals and pollutants (Mhamdi et al., 2010). Saline conditions induce osmotic stress from low soil water potential, toxicity and oxidative stress from reactive oxygen species (ROS) (Nounjan and Theerakulpisut, 2012). The production of ROS such as superoxide $\left(\mathrm{O}_{2}^{-}\right)$, hydrogen peroxide $\left(\mathrm{H}_{2} \mathrm{O}_{2}\right)$ and hydroxyl radical $\left(\mathrm{OH}^{\circ}\right)$ during salinity stress causes extensive oxidative damage to biomolecules like protein, DNA and lipids (Nounjan and Theerakulpisut, 2012; Weisany et al., 2012; Das and Roychoudhury, 2014). To counteract the ROS, plants generate non-enzymatic antioxidants as well as antioxidant enzymes i.e. peroxidase (POX), superoxide dismutase (SOD), ascorbate peroxidase (APX) and catalase (CAT) (Sairam and Tyagi, 2004). Several studies have pointed out that salt-tolerant species increased their antioxidant enzyme activities and antioxidant contents in response to salt treatment, whereas salt-sensitive species failed to do so (Shalata et al., 2001; Demiral and Türkan, 2005).

Catalase, a tetrameric heme-containing enzyme and the first antioxidant enzyme to be discovered, removes $\mathrm{H}_{2} \mathrm{O}_{2}$ by conversion into water and oxygen, and plays a key role in plant defense, aging, and senescence 
(Scandalios, 2002; Yang and Poovaiah, 2002). The catalase content continuously increased with salt treatments as compared to control in both the experimental years during Ca stress (Table 4). However, maximum catalase content was observed during $\mathrm{Na}$ stress at $200 \mathrm{mM}$ salt concentrations. There was about 9 -fold increase in catalase content for $\mathrm{Na}$ in $2017(7.15 \pm 0.44 \mathrm{U} / \mathrm{g} \mathrm{fw})$ and $2018(6.77 \pm 2.39 \mathrm{U} / \mathrm{g}$ fw $)$ as compared to control. Jakovljević et al. (2017) and Aghaei et al. (2009) have also reported increase in catalase content under high salt stress conditions in sweet basil (Ocimum basilicum) and potato (Solanum tuberosum).

Similar to catalase, the GST content increased with increase in salt concentration and was maximum at $200 \mathrm{mM}$ (Table 4). This increase in GST content was most prominent for $\mathrm{Na}$ and exhibited a 9-fold enhancement in $2017(8.10 \pm 1.05 \mathrm{~mol} / \mathrm{min} / \mathrm{mg}$ protein) and about 12 -fold increase in $2018(8.96 \pm 2.87$ $\mathrm{mol} / \mathrm{min} / \mathrm{mg}$ protein).

DPPH (2,2-diphenyl-1-picryl-hydrazyl-hydrate) free radical method, developed by Marsden Blois (1958), is an easy, rapid and most frequently employed assay for the evaluation of the antioxidant potential of a biological source by spectrophotometry (Kedare and Singh, 2011; Lalhminghlui and Jagetia, 2018). DPPH, a stable free radical possessing deep purple colour is reduced in the presence of an antioxidant molecule, giving rise to pale yellow solution, thus allowing the spectrophotometric determination of the antioxidant activity (Akar et al., 2017). In this study, the DPPH content increased when low concentration of salt treatment was provided and was maximum at $50 \mathrm{mM}$ salt concentration for $\mathrm{K}$ and $\mathrm{Na}$ (Table 4). After this initial rise in DPPH levels, the parameter gradually decreased with increase in salt concentrations and was lowest at $200 \mathrm{mM}$ salt concentrations for both $\mathrm{Na}(20.21 \pm 3.07 \mu \mathrm{g} / \mathrm{mL}$ and $30.37 \pm 3.28 \mu \mathrm{g} / \mathrm{mL}$ for 2017 and 2018), and $\mathrm{K}$ $(37.72 \pm 2.78 \mu \mathrm{g} / \mathrm{mL}$ and $32.23 \pm 1.41 \mu \mathrm{g} / \mathrm{mL}$ for 2017 and 2018 respectively) (Table 4).

Reduced glutathione is an $\mathrm{NAD}(\mathrm{P}) \mathrm{H}$-dependent enzyme that catalyses the reduction of oxidized glutathione to reduced its reduced form thereby protecting the cell against oxidative damage (Foyer and Noctor, 2005). The GSH content showed a consistent pattern of decrease with rising salt concentrations for all the salts in both the experimental years (Table 4). Similar results have been obtained in tomato (Solanum lycopersicum L.) under salt stress by Parvin et al. (2019).

SOD, belonging to the family of metalloenzymes omnipresent in all aerobic organisms, plays a key role in catalysing the dismutation reaction of the superoxide radical $\left(\mathrm{O}^{2-}\right)$ to hydrogen peroxide $\left(\mathrm{H}_{2} \mathrm{O}_{2}\right)$ and molecular oxygen and thus protects the cells from oxidative damage caused by ROS (Mohamed et al., 2016; Szymańska et al., 2017). In the present study low salt concentration of $50 \mathrm{mM}$ led to a slight increase in the SOD levels (Table 4). Such increase in SOD content of salt treated plants has also been reported earlier in Olea europaea (Valderrama et al., 2006), Robinia pseudoacacia (Meng et al., 2016) and Triticum aestivum (Esfandiari and Gohari, 2017). But excess salt treatment resulted in a significant decline in SOD levels. The SOD content was lowest for $\mathrm{Na}$ at $200 \mathrm{mM}$ in both the experimental years $(2.71 \pm 0.34 \mathrm{U} / \mathrm{g}$ fw and $1.98 \pm 0.16 \mathrm{U} / \mathrm{g} \mathrm{fw}$, respectively) (Table 4). 
Table 3. Changes in flavonoid, phenolics and protein in flax leaves and seed yield during salt stress.

\begin{tabular}{|c|c|c|c|c|c|}
\hline \multirow{3}{*}{$\begin{array}{l}\text { Trait } \\
\text { Phenolics (mg equivalent } \\
\text { gallic acid/g DW) }\end{array}$} & \multicolumn{4}{|c|}{2017} & \multirow[b]{2}{*}{$\mathrm{CaCl}$} \\
\hline & $\mathrm{CaCl}$ & & $\mathrm{KCl}$ & $\mathrm{NaCl}$ & \\
\hline & Mean & & Mean & Mean & Mean \\
\hline $0 \mathrm{mM}$ & $164.91 \pm 11.91$ & $\mathrm{a}$ & $169.97 \pm 13.20$ & $174.10 \pm 4.24 \quad \mathrm{a}$ & $145.07 \pm 7.5$ \\
\hline $50 \mathrm{mM}$ & $92.90 \pm 6.36$ & $\mathrm{~b}$ & $94.20 \pm 17.25 b$ & $93.40 \pm 6.79 \mathrm{~b}$ & $111.80 \pm 1.1$ \\
\hline $100 \mathrm{mM}$ & $99.30 \pm 12.87$ & $\mathrm{~b}$ & $103.70 \pm 12.87 \mathrm{~b}$ & $98.60 \pm 8.20 \mathrm{~b}$ & $127.20 \pm 12$ \\
\hline $150 \mathrm{mM}$ & $105.60 \pm 7.07$ & $\mathrm{~b}$ & $114.10 \pm 1.84$ & $107.60 \pm 9.05 b$ & $131.10 \pm 9.4$ \\
\hline $200 \mathrm{mM}$ & $110.60 \pm 9.62$ & $\mathrm{~b}$ & $116.00 \pm 3.11$ & $110.00 \pm 7.64 b$ & $133.90 \pm 8.3$ \\
\hline
\end{tabular}

Flavonoids (mg equivalent

QE/g of tissue)

$\begin{array}{rrl}0 \mathrm{mM} & 40.88 \pm 5.64 & \text { a } \\ 50 \mathrm{mM} & 35.55 \pm 0.26 & \text { ab } \\ 100 \mathrm{mM} & 33.57 \pm 0.04 & \text { ab } \\ 150 \mathrm{mM} & 32.19 \pm 0.19 & \text { ab } \\ 200 \mathrm{mM} & 30.59 \pm 0.26 & \mathrm{~b}\end{array}$

$\begin{array}{ll}42.06 \pm 2.77 & \mathrm{a} \\ 30.45 \pm 1.59 & \mathrm{ab} \\ 26.48 \pm 3.51 & \mathrm{~b} \\ 22.93 \pm 3.40 & \mathrm{~b} \\ 22.37 \pm 2.90 & \mathrm{~b}\end{array}$

$46.20 \pm 5.80 \quad 0$

$37.77 \pm 3.5$

$30.96 \pm 2.30 \mathrm{ab}$

$35.57 \pm 1.0$

$28.40 \pm 4.34 \mathrm{ab}$

$34.19 \pm 0.3$

$200 \mathrm{mM} \quad 30.59 \pm 0.26 \quad b$

$24.29 \pm 6.07 b$

$32.59 \pm 0.3$

$22.73 \pm 4.14 \quad b$

$30.64 \pm 0.3$.

Protein $(\%)$

$\begin{array}{rrc}0 \mathrm{mM} & 47.91 \pm 5.50 & \mathrm{a} \\ 50 \mathrm{mM} & 32.55 \pm 0.35 & \mathrm{~b} \\ 100 \mathrm{mM} & 19.35 \pm 0.49 & \mathrm{c} \\ 150 \mathrm{mM} & 9.40 \pm 0.28 & \mathrm{~d} \\ 200 \mathrm{mM} & 4.15 \pm 0.21 & \mathrm{~d}\end{array}$

$\begin{array}{rl}42.30 \pm 4.41 & \mathrm{a} \\ 22.00 \pm 0.85 & \mathrm{~b} \\ 19.70 \pm 0.42 & \mathrm{bc} \\ 12.20 \pm 0.28 & \mathrm{c} \\ 4.00 \pm 0.00 & \mathrm{~d}\end{array}$

$46.19 \pm 4.82$ a

$53.39 \pm 2.8^{\prime}$

$31.00 \pm 1.4$

$15.10 \pm 1.5$

$8.00 \pm 0.7$

$25.70 \pm 0.71 \mathrm{~b}$

$7.10 \pm 0.57 \mathrm{c}$

$5.10 \pm 0.1$.

Seed yield (g/plant)

$\begin{array}{rlllllll}0 \mathrm{mM} & 4.98 \pm 0.59 & \mathrm{a} & 5.17 \pm 0.23 & \mathrm{a} & 4.70 \pm 0.07 & \mathrm{a} & 5.24 \pm 0.2 \\ 50 \mathrm{mM} & 2.86 \pm 0.11 & \mathrm{~b} & 3.08 \pm 0.08 & \mathrm{~b} & 3.59 \pm 0.11 & \mathrm{~b} & 2.81 \pm 0.1 \\ 100 \mathrm{mM} & 1.98 \pm 0.08 & \mathrm{~b} & 1.91 \pm 0.12 & \mathrm{c} & 2.25 \pm 0.08 & \mathrm{c} & 1.93 \pm 0.1 \\ 150 \mathrm{mM} & 0.69 \pm 0.06 & \mathrm{c} & 1.17 \pm 0.10 & \mathrm{~d} & 1.17 \pm 0.07 & \mathrm{~d} & 0.67 \pm 0.0 \\ 200 \mathrm{mM} & 0.10 \pm 0.01 & \mathrm{c} & 0.25 \pm 0.05 & \mathrm{e} & 0.35 \pm 0.01 & \mathrm{e} & 0.08 \pm 0.0\end{array}$

Different letters within a column indicate significant differences according to Tukey's test ( $\mathrm{p} \leq 0.05)$. 
Table 4. Effect of salt stress on different antioxidant enzymes in flax leaves.

\begin{tabular}{|c|c|c|c|c|c|c|c|c|}
\hline \multirow{3}{*}{$\frac{\text { Trait }}{\text { Catalase (U/g fw) }}$} & & \multicolumn{5}{|c|}{2017} & \multirow{2}{*}{\multicolumn{2}{|c|}{$\mathrm{CaCl}$}} \\
\hline & & \multicolumn{2}{|l|}{$\mathrm{CaCl}$} & $\mathrm{KCl}$ & \multicolumn{2}{|l|}{$\mathrm{NaCl}$} & & \\
\hline & & Mean & & Mean & Mean & & Mean & \\
\hline & $0 \mathrm{mM}$ & $0.73 \pm 0.07$ & $\mathrm{a}$ & $0.82 \pm 0.17 \mathrm{a}$ & $0.83 \pm 0.04$ & $\mathrm{a}$ & $0.67 \pm 0.13$ & $\mathrm{a}$ \\
\hline & $50 \mathrm{mM}$ & $0.83 \pm 0.05$ & $\mathrm{a}$ & $0.80 \pm 0.08 \mathrm{a}$ & $0.31 \pm 0.01$ & $\mathrm{a}$ & $0.75 \pm 0.05$ & $\mathrm{a}$ \\
\hline & $100 \mathrm{mM}$ & $1.32 \pm 0.04$ & $\mathrm{a}$ & $0.60 \pm 0.05 \mathrm{a}$ & $0.68 \pm 0.06$ & $\mathrm{a}$ & $1.39 \pm 0.19$ & $\mathrm{a}$ \\
\hline & $150 \mathrm{mM}$ & $2.85 \pm 0.16$ & $\mathrm{~b}$ & $1.29 \pm 0.04 \mathrm{~b}$ & $1.72 \pm 0.11$ & $\mathrm{~b}$ & $3.01 \pm 0.34$ & $\mathrm{~b}$ \\
\hline & $200 \mathrm{mM}$ & $2.78 \pm 0.30$ & $\mathrm{~b}$ & $2.53 \pm 0.06 \mathrm{c}$ & $7.15 \pm 0.44$ & $\mathrm{c}$ & $2.51 \pm 0.09$ & $b$ \\
\hline \multicolumn{9}{|c|}{ GST (mol/min/mg protein) } \\
\hline & $0 \mathrm{mM}$ & $0.81 \pm 0.11$ & $\mathrm{a}$ & $0.96 \pm 0.06 \mathrm{a}$ & $0.92 \pm 0.09$ & $\mathrm{a}$ & $0.77 \pm 0.07$ & $\mathrm{a}$ \\
\hline & $50 \mathrm{mM}$ & $0.94 \pm 0.07$ & $\mathrm{a}$ & $1.33 \pm 0.05 \mathrm{ab}$ & $0.87 \pm 0.04$ & $\mathrm{a}$ & $0.93 \pm 0.07$ & $a b$ \\
\hline & $100 \mathrm{mM}$ & $1.90 \pm 0.05$ & $\mathrm{~b}$ & $1.53 \pm 0.05 b$ & $1.34 \pm 0.002$ & $a b$ & $1.66 \pm 0.24$ & $\mathrm{~b}$ \\
\hline & $150 \mathrm{mM}$ & $3.25 \pm 0.26$ & $\mathrm{c}$ & $2.85 \pm 0.17 \mathrm{c}$ & $2.83 \pm 0.05$ & $\mathrm{~b}$ & $2.93 \pm 0.30$ & $\mathrm{c}$ \\
\hline & $200 \mathrm{mM}$ & $5.41 \pm 0.27$ & $\mathrm{~d}$ & $5.39 \pm 0.11 \mathrm{~d}$ & $8.10 \pm 1.05$ & $\mathrm{c}$ & $3.98 \pm 0.26$ & $\mathrm{~d}$ \\
\hline \multicolumn{9}{|l|}{ DPPH $(\mu \mathrm{g} / \mathrm{mL})$} \\
\hline & $0 \mathrm{mM}$ & $9.18 \pm 0.54$ & $\mathrm{a}$ & $8.92 \pm 0.93 \mathrm{a}$ & $8.68 \pm 0.68$ & $\mathrm{a}$ & $8.02 \pm 0.38$ & $\mathrm{a}$ \\
\hline & $50 \mathrm{mM}$ & $53.69 \pm 0.53$ & $\mathrm{c}$ & $42.22 \pm 2.52 b$ & $39.38 \pm 3.46$ & $\mathrm{c}$ & $54.65 \pm 4.42$ & $\mathrm{c}$ \\
\hline & $100 \mathrm{mM}$ & $48.37 \pm 5.03$ & bc & $41.90 \pm 2.29 b$ & $35.67 \pm 1.21$ & $\mathrm{c}$ & $55.04 \pm 2.88$ & $\mathrm{c}$ \\
\hline & $150 \mathrm{mM}$ & $28.77 \pm 9.23$ & $\mathrm{ab}$ & $39.33 \pm 2.17 b$ & $30.34 \pm 2.98$ & bc & $30.64 \pm 3.15$ & $\mathrm{~b}$ \\
\hline & $200 \mathrm{mM}$ & $45.64 \pm 3.72$ & bc & $37.72 \pm 2.78 b$ & $20.21 \pm 3.07$ & $\mathrm{~b}$ & $47.04 \pm 1.39$ & $\mathrm{c}$ \\
\hline \multicolumn{9}{|l|}{$\mathrm{GSH}(\mu \mathrm{mol} / \mathrm{g} / \mathrm{min})$} \\
\hline & $0 \mathrm{mM}$ & $45.74 \pm 10.55$ & $\mathrm{a}$ & $41.32 \pm 6.31 b$ & $38.20 \pm 4.81$ & $\mathrm{~b}$ & $53.02 \pm 10.20$ & $\mathrm{~b}$ \\
\hline & $50 \mathrm{mM}$ & $45.05 \pm 0.62$ & $\mathrm{a}$ & $41.76 \pm 0.26 \mathrm{~b}$ & $38.87 \pm 1.80$ & $\mathrm{~b}$ & $43.30 \pm 1.14$ & $\mathrm{ab}$ \\
\hline & $100 \mathrm{mM}$ & $41.05 \pm 0.22$ & $\mathrm{a}$ & $39.51 \pm 0.49 b$ & $36.14 \pm 1.03$ & $\mathrm{~b}$ & $41.20 \pm 1.02$ & $\mathrm{ab}$ \\
\hline & $150 \mathrm{mM}$ & $37.81 \pm 0.80$ & $\mathrm{a}$ & $34.17 \pm 1.01 \mathrm{ab}$ & $33.47 \pm 1.00$ & $a b$ & $36.18 \pm 1.14$ & $\mathrm{ab}$ \\
\hline & $200 \mathrm{mM}$ & $32.91 \pm 0.12$ & $\mathrm{a}$ & $24.34 \pm 1.02 \mathrm{ab}$ & $25.12 \pm 1.57$ & $\mathrm{a}$ & $34.13 \pm 1.11$ & $\mathrm{a}$ \\
\hline \multicolumn{9}{|l|}{ SOD (U/g fw) } \\
\hline & $0 \mathrm{mM}$ & $8.17 \pm 0.21$ & $\mathrm{~b}$ & $8.60 \pm 0.25 b$ & $8.33 \pm 0.30$ & $\mathrm{~b}$ & $7.52 \pm 0.23$ & bc \\
\hline & $50 \mathrm{mM}$ & $14.33 \pm 0.97$ & $\mathrm{c}$ & $9.65 \pm 0.68 b$ & $18.87 \pm 0.22$ & $\mathrm{~d}$ & $12.72 \pm 0.41$ & d \\
\hline & $100 \mathrm{mM}$ & $8.08 \pm 1.07$ & $\mathrm{~b}$ & $8.99 \pm 0.14 b$ & $16.42 \pm 0.71$ & $\mathrm{c}$ & $8.92 \pm 1.16$ & $\mathrm{c}$ \\
\hline & $150 \mathrm{mM}$ & $6.49 \pm 0.77$ & $\mathrm{ab}$ & $6.19 \pm 0.18 \mathrm{a}$ & $8.16 \pm 0.32$ & $\mathrm{~b}$ & $5.72 \pm 0.47$ & $\mathrm{ab}$ \\
\hline & $200 \mathrm{mM}$ & $4.94 \pm 0.11$ & $\mathrm{a}$ & $5.17 \pm 0.20 \mathrm{a}$ & $2.71 \pm 0.34$ & $\mathrm{a}$ & $4.80 \pm 0.28$ & $\mathrm{a}$ \\
\hline
\end{tabular}

Different letters within a column indicate significant differences according to Tukey’s test $(\mathrm{p} \leq 0.05)$

\section{Conclusions}

The study showed that salt stress induced physiological changes in flax germplasm. Reductions in leaf pigment concentration were observed in plants exposed to high salt concentrations, indicating that salt stress reduced the capacity of the photosynthetic system for efficient energy conversion. The leaf protein content exhibited least reduction during Na stress, while seed yield was lowest during Ca stress. The catalase and GST content increased with increase in salt concentration and was maximum at $200 \mathrm{mM}$ for all the salt treatments.

\section{Acknowledgements}

The authors are thankful to Director, National Botanical Research Institute to provide the germplasm for carrying out the present work. 


\section{Conflict of Interests}

The authors declare that there are no conflicts of interest related to this article.

\section{References}

Aebi H (1974). Catalase. In: Bergmeyer HU (Ed). Methods of enzymatic analysis, Verlag Chemie/Academic Press Inc, Weinheim/NewYork, pp 673-680.

Aghaei K, Ehsanpour AA, Komatsu S (2009). Potato responds to salt stress by increased activity of antioxidant enzymes. Journal of Integrative Plant Biology 51:1095-1103.

Akar Z, Küçük M, Doğan H (2017). A new colorimetric DPPH• scavenging activity method with no need for a spectrophotometer applied on synthetic and natural antioxidants and medicinal herbs. Journal of Enzyme Inhibition and Medicinal Chemistry 32:640-647.

Arora I, Sharma M, Tollefsbol TO (2019). Combinatorial Epigenetics Impact of Polyphenols and Phytochemicals in cancer prevention and therapy. International Journal of Molecular Sciences 20:E4567.

Bari G, Godward MBE (1970). Interspecific crosses in Linum. Euphytica 19:443-446.

Bayrak A, Kiralan M, Ipek A, Arslan N, Cosge B, Khawar KM (2010). Fatty acid composition of linseed (Linum usitatissimum L.) genotypes of different origin cultivated in Turkey. Biotechnology and Biotechnology Equipment 24:1836-1842.

Bennett MD, Leitch IJ (2004) Plant DNA C-values database (release 3.0).

Bhargava A, Shukla S, Katiyar RS, Ohri D (2003). Selection parameters for genetic improvement in Chenopodium grain in sodic soil. Journal of Applied Horticulture 5:45-48.

Bhattacharya A, Sood P, Citovsky V (2010). The roles of plant phenolics in defence and communication during Agrobacterium and Rhizobium infection. Molecular Plant Pathology 11:705-719.

Blois MS (1958). Antioxidant determinations by the use of a stable free radical. Nature 181:1199-1200.

Bose J, Rodrigo-Moreno A, Shabala S (2014). ROS homeostasis in halophytes in the context of salinity stress tolerance. Journal of Experimental Botany 65:1241-1257.

Boudet A (2007). Evolution and current status of research in phenolic compounds. Phytochemistry 68:2722-2735.

Bradford MM (1976). A rapid and sensitive method for the quantitation of microgram quantities of protein utilizing the principle of protein-dye binding. Analytical Biochemistry 72:248-254.

Bui EN (2017). Causes of soil salinization, sodification, and alkalinization. Oxford Research Encyclopedia of Environmental Science.

Chaves MM, Flexas J, Pinheiro C (2009). Photosynthesis under drought and salt stress: Regulation mechanisms from whole plant to cell. Annals of Botany 103:551-560.

Chennaveeraiah MS, Joshi KK (1983). Karyotypes in cultivated and wild species of Linum. Cytologia 48:833-841.

Dai J, Mumper RJ (2010) Plant phenolics: extraction, analysis and their antioxidant and anticancer properties. Molecules 15:7313-7352.

Das K, Roychoudhury A (2014). Reactive oxygen species (ROS) and response of antioxidants as ROS-scavengers during environmental stress in plants. Frontiers in Environmental Science 2:53.

Demiral T, Turkan I (2005). Comparative lipid peroxidation, antioxidant defense systems and proline content in roots of two rice cultivars differing in salt tolerance. Environmental and Experimental Botany 53:247-257.

Durazzo A, Lucarini M, Souto EB, Cicala C, Caiazzo E, Izzo AA, Novellino E, Santini A (2019). Polyphenols: a concise overview on the chemistry, occurrence, and human health. Phytotherapy Research 33:2221-2243.

Esfandiari E, Gohari G (2017). Response of ROS-scavenging systems to salinity stress in two different wheat (Triticum aestivum L.) cultivars. Notulae Botanicae Horti Agrobotanici Cluj-Napoca 45:287-291.

Ellman GL (1959). Tissue sulphydryl groups. Archives of Biochemistry and Biophysics 82:70-77.

Fatma A, Sokindra K, Shah AK (2013). Estimation of total phenolic content, in-vitro antioxidant and anti-inflammatory activity of flowers of Moringa oleifera. Asian Pacific Journal of Tropical Biomedicine 3:623-627. 
Feller U, Vaseva II (2014). Extreme climatic events: impacts of drought and high temperature on physiological processes in agronomically important plants. Frontiers in Environmental Sciences 2:39.

Foyer CH, Noctor G (2005). Redox homeostasis and antioxidant signaling: a metabolic interface between stress perception and physiological responses. The Plant Cell 17:1866-1875.

Fraga CG, Croft KD, Kennedy DO, Tomás-Barberán FA (2019) The effects of polyphenols and other bioactives on human health. Food and Function 10:514-528.

Goyal A, Sharma V, Sihag MK, Singh AK, Arora S, Sabikhi L (2016). Fortification of dahi (Indian yoghurt) with omega-3 fatty acids using microencapsulated flaxseed oil microcapsules. Journal of Food Science and Technology 53:2422-2433.

Habig WH, Pabst MJ, Jacoby WB (1974). Glutathione $S$-transferases: the first enzymatic step in mercapturic acid formation. Journal of Biological Chemistry 249:7130-7139.

Hair JF, Anderson RE, Tatham RL, Black WC (1992). Multivariate data analysis. New York, Macmillan Publishing Company.

Harris BD (1968). Chromosome numbers and evolution in North American species of Linum. American Journal of Botany 55:1197-1204.

Heim KE, Tagliaferro AR, Bobilya DJ (2002). Flavonoid antioxidants: chemistry, metabolism and structure-activity relationships. Journal of Nutritional Biochemistry 13:572-584.

Hernández JA (2019). Salinity Tolerance in Plants: Trends and Perspectives. International Journal of Molecular Sciences 20:2408.

Heywood VH (1993). Flowering plants of the world. Oxford, Oxford Univ. Press.

Hickey M (1988). 100 families of flowering plants. Cambridge Univerity Press, Cambridge, UK.

$\mathrm{Hu}$ Y, Fromm J, Schmidhalter U (2005). Effect of salinity on tissue architecture in expanding wheat leaves. Planta 220:838-848.

Infostat (2019). InfoStat, Versión 2019. Grupo InfoStat, Facultad de Ciencias Agrarias, Universidad Nacional de Córdoba, Córdoba, Argentina.

Jakovljević DZ, Topuzović MD, Stanković MS, Bojović BM (2017). Changes in antioxidant enzyme activity in response to salinity-induced oxidative stress during early growth of sweet basil. Horticulture, Environment and Biotechnology 58:240-246.

Jamil A, Riaz S, Ashraf M, Foolad MR (2011). Gene expression profiling of plants under salt stress. Critical Reviews in Plant Science 30:435-458.

Jensen A (1978). Chlorophylls and carotenoids. In: Hellebust JA, Craigie JS (Eds). Handbook of physiological methods: physiological and biochemical methods, Cambridge University Press, Cambridge, pp 5-70.

Jiang N, Doseff AI, Grotewold E (2016). Flavones: From biosynthesis to health benefits. Plants (Basel) 5:27.

Kajla P, Sharma A, Sood DR (2015). Flaxseed- a potential functional food source. Journal of Food Science and Technology 52:1857-1871.

Kakkar PS, Das B, Viswanathan PN (1984). A modified spectrophoto-metric assay of superoxide dismutase. Indian Journal of Biochemistry and Biophysics 21:130-132.

Kawai Y (2018). Understanding metabolic conversions and molecular actions of flavonoids in vivo: toward new strategies for effective utilization of natural polyphenols in human health. Journal of Medical Investigation 65:162-165.

Kedare SB, Singh RP (2011). Genesis and development of DPPH method of antioxidant assay. Journal of Food Science and Technology 48:412-422.

Kevin AL, Emmanuel G, Ellen P (2002). Flavonoid quantification in onion by spectrophotometric and high-performance liquid chromatography analysis. HortScience 37:682-685.

Khataar, M, Mohammadi M, Shabani F (2018). Soil salinity and matric potential interaction on water use, water use efficiency and yield response factor of bean and wheat. Scientific Reports 8:2679.

Kikuchi M (1929). Cytological studies of the genus Linum L. Japanese Journal of Genetics 4:202-212.

Ksouri R, Megdiche W, Debez A (2007). Salinity effects on polyphenol content and antioxidant activities in leaves of the halophyte Cakile maritime. Plant Physiology and Biochemistry 45:244-249.

Lalhminghlui K, Jagetia GC (2018). Evaluation of the free-radical scavenging and antioxidant activities of Chilauni, Schima wallichii Korth in vitro. Future Science OA 4:FSO272.

Mahdi-Pour B, Jothy SL, Latha LY, Chen Y, Sasidharan S (2012). Antioxidant activity of methanol extracts of different parts of Lantana camara. Asian Pacific Journal of Tropical Biomedicine 2:960-965. 
Manach C, Scalbert A, Morand C, Remesy C, Jimenez L (2004). Polyphenols: food sources and bioavailability. American Journal of Clinical Nutrition 79:727-747.

McDill J, Repplinger M, Simpson BB, Kadereit JW (2009). The phylogeny of Linum and Linaceae subfamily Linoideae, with implications for their systematics, biogeography, and evolution of heterostyly. Systematic Botany 34:386-405.

Meng F, Luo Q, Wang Q, Zhang X, QiZ, Xu F, Lei X, Cao Y, Chow WS, Sun G (2016). Physiological and proteomic responses to salt stress in chloroplasts of diploid and tetraploid black locust (Robinia pseudoacacia L.). Scientific Reports 6:23098.

Mensor LL, Menezes FS, Leitao GG, Reis AS, dos Santos TC, Coube CS, Leitao SG (2001). Screening of Brazilian plant extracts for antioxidant activity by the use of DPPH free radical method. Phytotherapy Research 15:127-130.

Mhamdi A, Queval G, Chaouch S, Vanderauwera S, Van Breusegem F, Noctor G (2010). Catalase function in plants: a focus on Arabidopsis mutants as stress-mimic models. Journal of Experimental Botany 61:4197-4220.

Mohamed E, Matsuda R., El-Khatib AA, Takechi K, Takano H, Takio S (2016). Differential tolerance to high salt with regard to cell growth and superoxide dismutase (SOD) activity in calluses of the halophyte Suaeda maritima from Japan and Egypt. Plant Omics Journal 9:81-89.

Munns R, Tester M (2008). Mechanisms of salinity tolerance. Annual Review of Plant Biology 59:651-681.

Muravenko OV, Lemesh VA, Samatadze TE, Amosova AV, Grushetskaya ZE, Popov VK, ... Zelenin AV (2003). Genome comparisons with chromosomal and molecular markers for three closely related flax species and their hybrids. Russian Journal of Genetics 39:414-421.

Nounjan N, Theerakulpisut P (2012). Effects of exogenous proline and trehalose on physiological responses in rice seedlings during salt-stress and after recovery. Plant Soil and Environment 58:309-315.

Oomah BD, Kenaschuk EO, Mazza G (1995). Phenolic acids in flaxseed. Journal of Agricultural and Food Chemistry 43:20162019.

Pandolfi C, Bazihizina N, Giordano C, Mancuso S, Azzarello E (2017). Salt acclimation process: a comparison between a sensitive and a tolerant Olea europaea cultivar. Tree Physiology 37:380-388.

Parvin K, Hasanuzzaman M, Bhuyan MHMB, Nahar K, Mohsin SM, Fujita M (2019). Comparative physiological and biochemical changes in tomato (Solanum lycopersicum L.) under salt stress and recovery: role of antioxidant defense and glyoxalase systems. Antioxidants (Basel) 8:350.

Rahman MM, Rahman MA, Miah MG, Saha SR, Karim MA and Mostofa MG (2017). Mechanistic insight into salt tolerance of Acacia auriculiformis: the importance of ion selectivity, osmoprotection, tissue tolerance, and $\mathrm{Na}^{+}$exclusion. Frontiers in Plant Science 8:155.

Rahneshan Z, Nasibi F, Moghadam AA (2018). Effects of salinity stress on some growth, physiological, biochemical parameters and nutrients in two pistachio (Pistacia vera L.) rootstocks, Journal of Plant Interactions 13:73-82.

Robertson KR (1971). The Linaceae in the southeastern United States. Journal of Arnold Arboretum 52: 649-665.

Rogers CM, Harris BD (1966). Some new chromosome numbers in Linum. Madrono 18:179-180.

Russo R, Reggiani R (2015). Phenolics and antioxidant activity in flax varieties with different productive attitude. International Food Research Journal 22:1736-1739.

Sairam RK, Tyagi A (2004). Physiology and molecular biology of salinity stress tolerance in plants. Current Science 86:407-421. Scandalios JG (2002). The rise of ROS. Trends in Biochemical Sciences 27:483-486.

Shah SH, Houborg R, McCabe MF (2017). Response of chlorophyll, carotenoid and spad-502 measurement to salinity and nutrient stress in wheat (Triticum aestivum 1.). Agronomy 7:61.

Shahbaz M, Ashraf M (2013). Improving salinity tolerance in cereals. Critical Reviews in Plant Sciences 32:237-249.

Shalata A, Mittova V, Volokita M, Guy M, Tal M (2001). Response of the cultivated tomato and its wild salt-tolerant relative Lycopersicon pennellii to salt-dependent oxidative stress: the root antioxidative system. Physiologia Plantarum 112:487494.

Shrivastava P, Kumar R (2015). Soil salinity: A serious environmental issue and plant growth promoting bacteria as one of the tools for its alleviation. Saudi Journal of Biological Science 22:123-131.

Singh KK, Mridula D, Rehal J, Barnwal P (2011). Flaxseed: a potential source of food, feed and fiber. Critical Reviews in Food Science and Nutrition 51:210-222.

Sowndhararajan K, Kang SC (2013). Free radical scavenging activity from different extracts of leaves of Baubinia vahlii Wight \& Arn. Saudi Journal of Biological Sciences 20:319-325. 
Strogonov BP, Kabanov VV, Lapina LP, Prykhodko LS (1970). Structure and function of plant cells under salinity conditions. Nauka Publishing House Moscow.

Szymańska R, Ślesak I, Orzechowska A, Kruk J (2017) Physiological and biochemical responses to high light and temperature stress in plants. Environmental and Experimental Botany 139:165-177.

Taïbi K, Taibi F, Abderrahim LA, Ennajah A, Belkhodja M, Mulet JM (2016). Effect of salt stress on growth, chlorophyll content, lipid peroxidation and antioxidant defence systems in Phaseolus vulgaris L. South African Journal of Botany 105:306-312.

Tang L, Ying RR, Jiang D, Zeng XW, Morel JL, Tang YT, Qiu RL (2013). Impaired leaf CO2 diffusion mediates cd-induced inhibition of photosynthesis in the $\mathrm{zn} / \mathrm{cd}$ hyperaccumulator Picris divaricata. Plant Physiology and Biochemistry 73:7076.

Tardieu F (2013). Plant response to environmental conditions: assessing potential production, water demand, and negative effects of water deficit. Frontiers in Physiology 4:17.

Tohge T, Watanabe M, Hoefgen R, Fernie, AR (2013). The evolution of phenylpropanoid metabolism in the green lineage. Critical Reviews in Biochemistry and molecular Biology 48:3123-152.

Tutin TG, Heywood VH, Burges NA, Murre DM, Valentine DH, Walters SM, Webb DM (1968). Flora Europaea: Rosaceae to Umbelliferae. Cambridge, Cambridge Univ. Press.

Valderrama R, Corpas FJ, Carreras A, Gomez-Rodriguez MV, Chaki M, Pedrajas JR, ... Barroso JB (2006). The dehydrogenasemediated recycling of NADPH is a key antioxidant system against salt-induced oxidative stress in olive plants. Plant Cell and Environment 29:1449-1459.

Vromans J (2006). Molecular genetic studies in flax (Linum usitatissimum L.). Ph.D. diss. Wageningen, Wageningen University.

Weisany W, Sohrabi Y, Heidari G, Siosemardeh A, Ghassemi-Golezani K (2012). Changes in antioxidant enzymes activity and plant performance by salinity stress and zinc application in soybean (Glycine max L.). Plant Omics Journal 5:60-67.

Yang T, Poovaiah BW (2002). Hydrogen peroxide homeostasis: Activation of plant catalase by calcium/calmodulin. PNAS 99:4097-4102.

Yonekura-Sakakibara K, Higashi Y, Nakabayashi R (2019). The origin and evolution of plant flavonoid metabolism. Frontiers in Plant Science 10:943.

Zeven AC (1982). Dictionary of cultivated plants and their centers of diversity, excluding ornamentals, forest trees and lower plants. Center for Agricultural Publishing and Documentation, Wageningen, The Netherlands.

Zohary D, Hopf M (2000). Domestication of plants in the old world. Oxford, Oxford University Press.
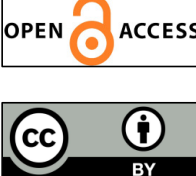

The journal offers free, immediate, and unrestricted access to peer-reviewed research and scholarly work. Users are allowed to read, download, copy, distribute, print, search, or link to the full texts of the articles, or use them for any other lawful purpose, without asking prior permission from the publisher or the author.

License - Articles published in Notulae Botanicae Horti Agrobotanici Cluj-Napoca are Open-Access, distributed under the terms and conditions of the Creative Commons Attribution (CC BY 4.0) License. (C) Articles by the authors; UASVM, Cluj-Napoca, Romania. The journal allows the author(s) to hold the copyright/to retain publishing rights without restriction. 